\title{
ARCHEOLOGIA ODPOWIEDZIALNA SPOLECZNIE. DZIALANIA Z ZAKRESU PUBLIC I COMMUNITY ARCHAEOLOGY W POLSCE
}

\author{
SOCIALLY RESPONSIBLE ARCHAEOLOGY. PUBLIC \\ AND COMMUNITY ARCHAEOLOGY ACIVITIES IN POLAND
}

\author{
Michat Pawleta \\ https://orcid.org/0000-0002-0466-1901 \\ Wydział Archeologii Uniwersytetu im. Adama Mickiewicza \\ ul. Uniwersytetu Poznańskiego 7, 61-614 Poznań \\ mpawleta@amu.edu.pl
}

\begin{abstract}
This paper aims to conceptualize the social role of archaeology and archeological heritage in the present. First, it contextualizes the legal and doctrinal background of activities aimed at dissemination of cultural and archaeological heritage and engagement of public in initiatives around that heritage. Next, it describes main forms of outreach activities undertaken by archaeologists in Poland. Further, it presents community-oriented activities and initiatives that go beyond education of the general public about the past and archaeology and strive for engaging local communities in activities centered around archaeology and archaeological heritage. It concludes with a statement that openness of archaeology to society helps to strengthen its current social position, determines its role in the world and attributes social activities of archaeologists with a deeper meaning.
\end{abstract}

KEYWORDS: archaeological heritage, public archaeology, community archaeology, dissemination, social role of archaeology, Poland

Ponad dwie dekady temu prof. Stanisław Tabaczyński poczynił ważną uwagę, która do dzisiaj niezmiennie zachowuje swoją aktualność. Stwierdził mianowicie, że jednym z głównych wyzwań stojących przed archeologią jest to, że powinna ona „sprostać nie tylko wymogom ścisłości naukowej, lecz także wyjść naprzeciw potrzebom i oczekiwaniom społecznym. Winna być społecznie akceptowana, budzić zainteresowanie i poczucie identyfikacji z deklarowanymi wartościami” (Tabaczyński, 1997, s. 29-30). Zawarty w powyższym cytacie komponent aksjologiczny wynika 
zarówno z samego przedmiotu badań archeologii (merytorycznej wartości odkrywanych i badanych przez badaczy materialnych pozostałości przeszłości), jak również z ich złożonej, często problematycznej wartości społecznej (Zalewska, 2016, s. 126). Jest on szczególnie istotny obecnie, gdy w stopniu znacznie większym niż uprzednio mamy do czynienia $\mathrm{z}$ ukierunkowaniem tej dyscypliny na działalność pozapoznawczą i na pełnione przez nią funkcje światopoglądowo-edukacyjne (Pałubicka, 1997, s. 130).

Piętnaście lat później ukazała się książka Michaela Shanksa The archaeological imagination. Autor przedstawia w niej wyobraźnię archeologiczną jako rodzaj twórczej pracy archeologów nad pozostałościami przeszłości lub „wrażliwości rozproszonej przez kulturowy odbiór przeszłości”" (Shanks, 2012, s. 15). Wskazuje przy tym na szczególną rolę archeologów jako tych, którzy za pomocą kreatywnej, archeologicznej wyobraźni „odtwarzają świat znajdujący się za ruinami” i „wskrzeszają” ludzi z przeszłości. Wyobraźnia archeologiczna, będąca zanurzona w licznych dyskursach kulturowych, predyspozycjach czy instytucjach ,jest zakorzeniona we wrażliwości, wszechobecnym zbiorze postaw wobec śladów i pozostałości, wobec pamięci, czasu i doczesności" (Shanks, 2015, s. 25). Immanentnym elementem tych postaw wobec przeszłości jest właśnie teraźniejszość.

Owo zakotwiczenie archeologii w teraźniejszości i zorientowanie na jej potrzeby doskonale zdiagnozował Laurent Olivier w tekście The business of archaeology is the present (2013). Francuski archeolog podkreśla, że archeolodzy muszą skupić się na teraźniejszości, która jest domeną ich działania oraz na samej materii, z którą pracują. Zasadniczo, jak wskazuje dalej, jest to misja polityczna, którą musimy realizować, jeśli archeologia chce odgrywać ważną rolę społeczną (Olivier, 2013, s. 128). W takim aspekcie teraźniejszość jest więc raisons d'être archeologii, zaś jej istotą jest wpływ na teraźniejszość.

Spoglądając z takiej perspektywy na archeologię, możemy stwierdzić, że przedmiot jej badania nie odnosi się wyłącznie do przeszłości, nie zajmuje się ona jedynie badaniem rzeczy z przeszłości i nie dotyczy jej poznawania na podstawie materialnych reliktów, lecz winna być przede wszystkim rozumiana jako „układ relacji w teraźniejszości" (Holtorf, 2005, s. 12). Tym samym uprawianie archeologii to pewien sposób myślenia, postrzegania oraz doświadczania otaczającego świata tu i teraz.

Podobnie, z perspektywy optyki teraźniejszości, możemy spojrzeć na dziedzictwo archeologiczne. Dotychczasowe, dominujące nadal, postrzeganie dziedzictwa, ukształtowane zostało w ramach tzw. „usankcjonowanego dyskursu dziedzictwa” (ang. authorized heritage discourse). Koncentruje się on na materialnych obiektach lub miejscach o wyjątkowych cechach estetycznych, o które obecne pokolenie powinno dbać, chronić je i przekazać przyszłym pokoleniom w celach edukacyjnych oraz aby kształtować poczucie tożsamości opartej na przeszłości. Sednem tego dyskursu jest idea, wedle której wartość kultury materialnej jest pierwotna, a nie jej przypisana. Dziedzictwo jest postrzegane jako kruche, skończone i nieodnawialne, co impliku- 
je konieczność objęcia go stałą opieką przez grono ekspertów (archeologów, historyków, architektów), których główne zadanie polega na zgłębianiu i przekazywaniu społeczeństwu immanentnych wartości dziedzictwa (Smith, 2006, s. 29-34; 2016, s. 27-30).

W reakcji na dominujący, autoryzowany, ekspercki dyskurs dziedzictwa ukształtowała się postawa kontestująca takie jego rozumienie, która znalazła wyraz w rozwoju krytycznych studiów nad dziedzictwem (ang. critical heritage studies - zob. m.in. Smith, 2006; Harrison, 2013). Wskazano, że dziedzictwo to pojęcie o rozległym zasięgu semantycznym, który odnosi się zarówno do jego wymiaru materialnego, jak i niematerialnego. Co więcej, ulega ono bezustannej zmianie pod wpływem aktualnych trendów czy pełnienia społecznych funkcji. Dziedzictwo należy rozumieć nie jako zbiór rzeczy czy przedmiotów materialnych, lecz jako swoistą postawę wobec przeszłości, która obejmuje także stosunek do tego dziedzictwa, polegający na angażowaniu go w procesy produkcji kulturowej. Ważne jest przy tym rozpoznanie wartości dziedzictwa przez odbiorców, jak i tej, która tkwi w samym obiekcie i ma znaczenie dla społeczności, ponieważ odgrywa istotną rolę w jego definiowaniu. Dziedzictwo postrzegane jest więc współcześnie nie tyle jako spadek z przeszłości, ale jako zbiór ,konstruowanych i sterowanych popytem współczesnych zastosowań" (Ashworth, 2007, s. 33). Zawsze jest to świadomy wybór cenionych przedmiotów i praktyk, dokonany przez grupy lub jednostki, który kształtuje poczucie tożsamości i stanowi o trwaniu danej wspólnoty. Laurajane Smith (2006, s. 4) uważa, że dziedzictwo jest przede wszystkim praktyką społeczną, kulturowym i społecznym procesem, obejmującym akty przypominania, które sprawiają, że zaczynamy rozumieć i angażować się w teraźniejszość. Dziedzictwo tworzy się w aktach negocjacji, przez wykorzystywanie przeszłości oraz zbiorowej lub indywidualnej pamięci, w celu kreowania nowych sposobów bycia i wyrażania własnej tożsamości. Nie odnosi się więc ono tylko do przeszłości czy rzeczy materialnych, lecz jest procesem zaangażowania, aktem komunikacji i tworzenia znaczeń zarówno w, jak i dla teraźniejszości. W przeciwieństwie więc do zabytku-dokumentu dziedzictwo należy do współczesności: służy teraźniejszym celom, może być przekształcane i dostosowywane. Ma ono także swojego właściciela, może być różnie interpretowane, wartościowane i wykorzystywane (Szmygin, 2007, s. 134). Definiowanie i podejmowanie decyzji dotyczące jego zarządzania wymyka się tym samym z rąk ciał eksperckich na rzecz zaangażowania w te procesy różnych grup interesariuszy dziedzictwa.

Ujmując zarówno archeologię, jak i dziedzictwo z perspektywy teraźniejszości, należy skonstatować, że w takiej optyce rola archeologii nie będzie sprowadzać się jedynie do poznawania prawdy o przeszłości. Kluczowe bowiem znaczenie ma w tym przypadku nie tyle relacja archeologów z obiektywną wiedzą naukową na temat przeszłości, lecz ze społeczeństwem, do którego należy oraz ukazywanie wzajemnych związków. Jednym z nich jest określanie i formowanie relacji ludzi z dziedzictwem przez jego upowszechnianie i udostępnianie. Ma to dwojaki cel. Po pierwsze udostęp- 
nianie i upowszechnianie dziedzictwa archeologicznego, jak również angażowanie społeczeństwa w praktyki i działania skoncentrowane wokół zasobów dziedzictwa skutkuje jego poszanowaniem, zrozumieniem i wspólną ochroną, będąc w interesie społeczeństwa, dziedzictwa archeologicznego i archeologii. Po drugie zaś otwarcie się archeologii na społeczeństwo pomaga wzmacniać jej pozycję i określić jej ważną rolę, w zgodzie z wartościami społecznymi, jak również nadawać głębszy sensu społecznym działaniom archeologów.

\section{ARCHEOLOGIA W KRYZYSIE}

Obecne można zaobserwować fundamentalne przewartościowania w podejściu do archeologii, jak również do dziedzictwa archeologicznego. W Polsce, w kontekście upadku i stopniowej erozji paradygmatu naukowego, archeologia została zmuszona do opuszczenia bezpiecznej „wieży z kości słoniowej” (Kobyliński, 2002). $Z$ racji tego, że na wielu płaszczyznach wchodzi ona we wzajemne relacje ze społeczeństwem, nie może być dłużej praktykowana i rozumiana tylko i wyłączne z czysto naukowego punktu widzenia.

Spojrzenie to zostało pogłębione przez kryzys ekonomiczny z 2008 roku, który odbił się poważnie na archeologii w wielu krajach Europy, w tym również w Polsce (Schlanger, Aitchison, 2010). W jego konsekwencji zauważono konieczność przedefiniowania funkcjonowania dyscypliny i uwypuklenia jej bardziej praktycznego społecznie wymiaru oraz dostarczania ludziom wiedzy o bardziej użytecznym i istotnym społecznie wymiarze (Kajda, Kobiałka, 2017, s. 28-29). Zmiana podejścia w tym zakresie jest bardziej zauważalna w tych krajach, które odczuły kryzys ekonomiczny w stopniu znacznie poważniejszym niż Polska. Jak wskazują dalej przywołani autorzy, poskutkowało to pojawianiem się i rozwojem licznych inicjatyw związanych m.in. z archeologią publiczną, archeologią społeczności lokalnych czy tzw. archeologią włączającą (ang. inclusive archaeology). Nowe, pokryzysowe podejście do archeologii oznaczało więc skoncentrowanie się na archeologii, która może odgrywać istotną rolę w społeczeństwie z perspektywy problemów i wyzwań współczesnego świata, takich jak głód, bieda, migracje, wykluczenie społeczne, prawa człowieka, zrównoważony rozwój, ochrona przyrody itd. Takie sposoby uprawiania archeologii - kontynuują Kajda i Kobiałka - stały się pożądane, ponieważ przez bezpośrednie angażowanie społeczeństwa w procesy poznawania i odkrywania przeszłości ukazują one praktyczne oblicze tej dyscypliny jako dziedziny o szerokim wymiarze i znaczeniu społecznym. Stąd również zwrot w stronę obserwowania i aktywnego włączania się archeologów w debaty dotyczące kwestii społecznych, a także poszukiwanie nowych pól badawczych (m.in. archeologie współczesności), które do tej pory wymykały się szerszej uwadze archeologów. Pozwoliło to także na zrozumienie, że archeologia to nie tylko nauka, forma wiedzy, zespół działań czy metod badawczych, lecz również forma praktyki społecznej i kulturowej, zależna od wydarzeń i problemów współczesności (Kajda, Kobiałka, 2017, s. 30). 


\section{UPOWSZECHNIANIE DZIEDZICTWA W ŚWIETLE DOKUMENTÓW DOKRTYNALNYCH}

Wdrażanie strategii działań w stosunku do dziedzictwa realizowane jest przez określanie pewnych obszarów priorytetowych i wyznaczanie celów strategicznych w tym zakresie. W Polsce są one definiowane w ramach „Krajowego programu ochrony zabytków i opieki nad zabytkami”, uchwalanym przez Radę Ministrów, zgodnie z zapisami Ustawy z dnia 23 lipca 2003 roku o ochronie zabytków i opiece nad zabytkami (DZ.U. z 2018 r., poz. 2067, z późn. zm.). Każdorazowo określa on cele administracji rządowej oraz podległych jej instytucji w zakresie ochrony zabytków i opieki nad zabytkami na okres czterech lat. Wskazuje także szczegółowo kierunki działań i zadania w tym zakresie (Musiał-Gąsiorowska, 2019, s. 30). Na przykład jednym ze strategicznych celów programu na lata 2014-2017 było „tworzenie warunków do aktywnego uczestnictwa w kulturze, edukacji na rzecz dziedzictwa kulturowego oraz jego promocji i reinterpretacji”, a jednym z kierunków działań było przygotowanie ratyfikacji „Ramowej konwencji Rady Europy dotyczącej znaczenia dziedzictwa kulturowego dla społeczeństwa" z Faro z 2005 roku, która jednak do dziś nie została ratyfikowana przez Polskę ${ }^{1}$. Natomiast jednym z celów programu na lata 2019-2022 jest budowanie wartości społecznej dziedzictwa kulturowego, co obejmuje też działania w zakresie popularyzowania i upowszechniania wiedzy o dziedzictwie kulturowym, budowania świadomości lokalnej, a także włączania społeczeństwa w opiekę nad zasobem dziedzictwa kulturowego².

Cele i zadania określane w tych programach stanowią pochodną szerszego spojrzenia na dziedzictwo, zakres jego zarządzania oraz ochrony. Są one modyfikowane i uzupełniane $\mathrm{w}$ zależności od zmian w podejściu do rozumienia dziedzictwa zawartego w dokumentach doktrynalnych i aktach międzynarodowych, regulujących kwestie dotyczące dziedzictwa, jakie wynikają ze zmieniających się potrzeb i wyzwań. Aktualnie w tym względzie zauważalny jest nowy, oddolny, społeczny oraz otwarty wymiar dziedzictwa kulturowego, zarówno w zakresie jego tworzenia, jak i podtrzymywania, ochrony i podejmowania dotyczących go decyzji. W licznych konwencjach odnoszących się do dziedzictwa, w tym dziedzictwa archeologicznego, akcentuje się, że jest ono źródłem istotnych wartości dla określonej społeczności, która jest zarazem zobowiązana do zarządzania powierzonymi jej zasobami. Owo zobowiązanie staje tym istotniejsze, że zgodnie z Konwencją z Faro z 2005 roku $^{3}$ podkreśleniu uległo

${ }^{1}$ Uchwała nr 125/2014 Rady Ministrów z dnia 24 czerwca 2014 r. w sprawie „Krajowego programu ochrony zabytków i opieki nad zabytkami”, zob. http://bip.mkidn.gov.pl/media/download_gallery/20140818Krajowy_Program_Ochrony_Zabytkow_i_Opieki_nad_Zaby.pdf [dostęp: 10.06.2020].

2 Uchwała nr 82 Rady Ministrów z dnia 13 sierpnia 2019 r. w sprawie „Krajowego programu ochrony zabytków i opieki nad zabytkami na lata 2019-2022”, zob. http://isap.sejm.gov.pl/isap.nsf/download. xsp/WMP20190000808/O/M20190808.pdf [dostęp: 10.06.2020].

3 Konwencja ramowa Rady Europy nr 199 w sprawie znaczenia dziedzictwa kulturowego dla społeczeństwa, Faro, 27.10.2005 r. Treść Konwencji opublikowana w: Szmygin, 2015, s. 164-170. Cytaty pochodzą z tej publikacji. 
znaczenie partycypacji społecznej jako kluczowej dla zachowania dziedzictwa kulturowego.

W przywołanej konwencji stwierdzono m.in., że „,elem ochrony dziedzictwa kulturowego i zrównoważonego korzystania z niego jest rozwój człowieka i poprawa jakości życia" (art. 1c). Dostęp do dziedzictwa został uznany za niezbywalne prawo każdego człowieka, co więcej, po raz pierwszy w tak wyraźny sposób podkreślono relację między dziedzictwem a rozwojem człowieka. Wprowadzono w niej także pojęcie „wspólnot dziedzictwa” (ang. heritage communities), czyli wspólnot składających się „,z ludzi ceniących określone aspekty dziedzictwa kulturowego, które chcą podtrzymać i przekazać przyszłym pokoleniom w ramach działań publicznych" (art. 2b). W innym miejscu konwencji znajduje się zapis, że „każdy, indywidualnie lub zbiorowo, ma prawo korzystać z dziedzictwa kulturowego i przyczyniać się do jego wzbogacania" (art. 4a). Stwierdzenie to wyraźnie akcentuje różnice w intepretowaniu dziedzictwa, a co za tym idzie również i konsekwencje wynikające z konfliktu wartości różnych wspólnot.

Z kolei w artykule 12 Konwencji z Faro, dedykowanym dostępowi do dziedzictwa kulturowego i demokratyzacji uczestnictwa, znajduje się zapis, że strony konwencji zobowiązują (się)

a) każdego do udziału w: - procesie identyfikacji, badania, interpretowania, ochrony, konserwacji i prezentacji dziedzictwa kulturowego; - debacie i refleksji publicznej o możliwościach i wyzwaniach stawianych przez dziedzictwo kulturowe;

b) uwzględniać wartość przypisywaną dziedzictwu kulturowemu przez każdą wspólnotę dziedzictwa, która się z nim identyfikuje;

c) uznać rolę organizacji wolontariackich, zarówno jako partnerów w działaniach, jak i konstruktywnych krytyków polityki dziedzictwa kulturowego;

d) podjąć kroki w celu poprawy dostępu do dziedzictwa, szczególnie dla osób młodych i znajdujących się w niekorzystnej sytuacji, w celu podniesienia świadomości o jego wartości, potrzebie utrzymania go w sprawności, zachowania oraz korzyści z niego płynących.

W zapisie tym wyraźnie przesunięty został akcent z podejmowania jedynie działań na rzecz zachowania i ochrony dziedzictwa „jako takiego" na umożliwienie korzystania z jego różnych wartości wszystkim zainteresowanym stronom.

Jednym z istotnych zagadnień, podkreślanych we współczesnych podejściach do dziedzictwa kulturowego (archeologicznego), jest kwestia jego prezentacji, upowszechniania i udostępniania szerokiemu gronu odbiorców. W przypadku archeologii sprowadza się to do działalności popularyzatorskiej, którą należy rozumieć jako działanie „mające na celu przybliżenie i wyjaśnienie osobom, do których jest kierowana, pewny pojęć związanych z daną dziedziną oraz skłonienie ich do dalszego poszerzania zasobu wiadomości i wykorzystywania własnego potencjału" (Kozakiewicz, 2012, s. 655). Działania te określają tym samym funkcję edukacyjno-popularyzatorską archeologii, polegająca na przekazywaniu społeczeństwu wiedzy na temat badanej przez nią przeszłości oraz upowszechnianiu wiedzy 
archeologicznej (np. Chowaniec, 2010; Wrzesiński, Wyrwa, 2010; Chowaniec, Więckowski, 2012).

Konieczność upubliczniania wiedzy, stanowiąca obowiązek archeologów, wynikająca m.in. z tego, że archeologia w sposób naukowy bada przeszłość, wskazywana jest w licznych konwencjach dotyczących ochrony dziedzictwa archeologicznego, jak również w kodeksach etyki zawodowej archeologów. Na przykład w „Karcie ochrony i zarządzania dziedzictwem archeologicznym" z Lozanny (1990) w artykule 7 wskazano, że

prezentacja dziedzictwa archeologicznego opinii publicznej jest istotnym sposobem upowszechniania wiedzy o pochodzeniu i rozwoju nowoczesnych społeczeństw. Jednocześnie jest to najważniejszy sposób wpływający na rozumienie potrzeby ochrony dziedzictwa archeologicznego. Prezentację i informację można uznać za popularną formę przekazywania obecnego stanu wiedzy i dlatego należy ją stale aktualizować. Należy wziąć pod uwagę wielostronne możliwości interpretacji i budzenie zrozumienia przeszłości. ${ }^{4}$

Z kolei „Europejska konwencja o ochronie dziedzictwa archeologicznego” z La Valetta z 1992 roku w artykule 9 dotyczącym kształtowania świadomości publicznej zaznacza, że każdy z jej sygnatariuszy zobowiązuje się:

(i) prowadzić działalność edukacyjną w celu wzbudzania i rozwijania w opinii publicznej świadomości o wartości dziedzictwa archeologicznego dla zrozumienia przeszłości i niebezpieczeństw, jakie mu zagrażają, (ii) promować publiczny dostęp do znaczących przedmiotów własnego dziedzictwa archeologicznego, w szczególności stanowisk archeologicznych, i zachęcać do publicznej ekspozycji wybranych obiektów archeologicznych. ${ }^{5}$

Podobne zapisy znalazły się z kodeksach etyki zawodowej dla społeczności archeologów w Polsce. „Zbiór zasad postępowania i norm etycznych środowiska archeologów w Polsce", opracowany i uchwalony przez Komitet Nauk Pra- i Protohistorycznych PAN w 2003 roku, zawiera następujący zapis w kwestii upowszechniania wiedzy:

archeolog powinien podejmować działania polegające na informowaniu opinii publicznej zarówno o wynikach konkretnych przedsięwzięć badawczych, jak i ogólnych celach i metodach zdobywania wiedzy o pradziejach, poprzez wykorzystywanie różnorodnych dostępnych środków informacji, takich jak audycje radiowe i telewizyjne, wywiady prasowe, publikacje popularno-naukowe, programy szkolne i inne inicjatywy edukacyjne (pkt. IV, ust. 1). ${ }^{6}$

${ }^{4}$ „Karta ochrony i zarządzania dziedzictwem archeologicznym ICAHM - ICOMOS” (1990). Treść karty opublikowano w: Szmygin, 2015, s. 95-98. Cytaty pochodzą z tej publikacji.

5 „Europejska konwencja o ochronie dziedzictwa archeologicznego" z La Valetta z 1992 roku. Treść karty opublikowano w: Szmygin, 2015, s. 105-110. Cytaty pochodzą z tej publikacji.

${ }^{6}$ Zob. http://www.archekom.pan.pl/index.php?option=com_content\&view=article\&id=68:zbior-zasad-postpowania-i-norm-etycznych-rodowiska-archeologow-w-polsce\&catid=32:aktualnoci-i-wydarzenia\&Itemid=46 [dostęp: 10.06.2020]. 
Natomiast „Kodeks postępowania członka Stowarzyszenia Naukowego Archeologów Polskich" z 2010 roku w Preambule stwierdza następująco:

dziedzictwo archeologiczne stanowi wspólną własność całej ludzkości. Jest ono nieodtwarzalne, ograniczone i narażone na zniszczenie. Archeologia polega na jego badaniu i interpretacji dla dobra całego społeczeństwa. Archeolodzy, jako grupa zawodowa, są opiekunami dziedzictwa archeologicznego, działającymi w imieniu innych ludzi. Społeczeństwo ma prawo do informacji o dziejach człowieka, jakie czerpiemy z badań archeologicznych oraz prawo do nieniszczącego, kulturowego, edukacyjnego i rekreacyjnego wykorzystywania dziedzictwa archeologicznego. ${ }^{7}$

Rola tak pojmowanej edukacji i popularyzacji archeologii i wiedzy o dziedzictwie archeologicznym polega na docieraniu z treściami ustalonymi w badaniach do jak najszerszego grona osób, o różnym poziomie przygotowania, kompetencji oraz wiedzy. Celem tych zabiegów jest głównie kształtowanie wiedzy na temat przeszłości, przez podawanie do publicznej wiadomości, w sposób dopasowany do percepcji i zrozumiały dla przeciętnych odbiorców, wyników badań, odkryć czy interpretacji archeologicznych, a przez to zwiększanie świadomości na temat konieczności ochrony dziedzictwa archeologicznego i powinności archeologów, a także pozostałych członków społeczeństwa w tym zakresie. Należy zauważyć, że nie są to nowe wskazania, ponieważ w środowisku archeologów świadomość konieczności upowszechniania wyników swych badań istnieje od dawna i na tym polu podejmowano bardzo liczne i zróżnicowane inicjatywy (np. Chowaniec, 2010, s. 53-104). Obecnie, w aktualnym kontekście społeczno-kulturowym i ekonomicznym, nabierają one jednak nowego znaczenia i wymowy, z jeszcze silniejszym akcentem na konieczność pełnienia funkcji edukacyjno-popularyzatorskiej. Ostatnie lata odzwierciedlają bowiem pojawianie się w środowisku archeologów świadomości etycznej odpowiedzialności ich profesji wobec dziedzictwa archeologicznego oraz wobec społeczeństwa. Jak zauważa Zbigniew Kobyliński (2012, s. 182), stanowią one wyraz „dojrzałości tej dyscypliny badawczej i utraty przez nią niewinności, polegającej na przekonaniu o możliwości zachowania moralnej neutralności w zmieniającej się dynamicznie współczesności”.

\section{ARCHEOLOGIA DLA SPOLECZEŃSTWA / ARCHEOLOGIA PROSPOLECZNA}

Reakcją i odpowiedzią środowiska archeologicznego na sygnalizowane wyżej przemiany stanowią archeologia publiczna i archeologia wspólnotowa. Działania podejmowane na ich gruncie mieszczą się w polu, które - za Anną Zalewską - można określić mianem „społecznego obiegu wiedzy archeologicznej” lub „archeologii uspołecznionej” (Zalewska, 2014, s. 21, 42). Poszerzając trójstopniową strukturę

\footnotetext{
${ }^{7}$ Zob. http://snap.org.pl/dokumenty/kodeks-etyki/ [dostęp: 10.06.2020].
} 
procesu archeologicznego, zaproponowaną i rozwijaną przez Stanisława Tabaczyńskiego (1987, s. 43), który wydzielił trzy główne domeny, mianowicie proces społeczno-kulturowy, na którym koncentruje się pierwotna uwaga badacza, pochodne od niego procesy źródłotwórcze oraz procesy poznawcze i badawcze, A. Zalewska wskazuje na konieczność bardziej konsekwentnego i obligatoryjnego niż dotychczas poszerzenia struktury tego procesu o czwartą domenę. Proponuje określać ją jako procesy uspołeczniania archeologii, które są tożsame ze społecznym obiegiem wiedzy o przeszłości kreowanej na podstawie jej materialnych pozostałości (Zalewska, 2014, s. 25). Wskazuje, że domena ta jest szczególnie ważna z uwagi na bieżące przemiany społeczne oraz rosnącą samorefleksyjność archeologii. Aczkolwiek, zdaniem autorki, zawierają się $\mathrm{w}$ niej zagadnienia postrzegane przez wielu przez badaczy przeszłości jako nienaukowe, jest ona szczególnie pomocna w uzmysłowieniu sobie dwóch kwestii. Po pierwsze, że archeolodzy nie są już jedynymi podmiotami sprawczymi we wspólnocie interpretacyjnej i komunikacyjnej, w której funkcjonują zarówno oni, jak i relikty przeszłości. Po drugie zaś, że ich działalność poznawcza kreuje kontekst kulturowo-społeczny i jest zarazem kreowana przez ten kontekst.

Istotne zmiany na polu relacji między archeologami a społeczeństwem mają dość długą tradycję i zostały zainicjowane w latach 70. ubiegłego stulecia, wraz z publikacją pracy Charlesa McGimsey'a Public archaeology (1972). Zdefiniował on w niej archeologię publiczną jako wzajemne relacje między archeologią a społeczeństwem. Odwoływał się przy tym do kwestii ochrony dziedzictwa i konieczności zachowania go dla przyszłych pokoleń, jak również do powszechnego prawa do wiedzy, pozyskanej w wyniku prowadzonych prac wykopaliskowych. Zwrócił także uwagę na to, że ochrona zabytków i upowszechnianie społeczeństwu wiedzy o archeologii i dziedzictwie archeologicznym jest nie tylko prawem, lecz obowiązkiem każdego badacza. Akcentował również konieczność zaangażowania społeczeństwa w badania archeologiczne. Takie spojrzenie w kolejnych latach doprowadziło do rozwoju szerokiego nurtu, określanego mianem archeologii publicznej (Schadla-Hall, 1999, 2006; Merriman, 2004; Deskur, 2009; Matsuda, Okamura, 2011; Skeates, McDavid, Carman, 2012; Moshenska, 2017; Gürsu, 2019; Williams, Pudney, Ezzeldin, 2019). Można ją zdefiniować jako „każdą formę działalności archeologicznej, która oddziałuje lub przynajmniej może wchodzić we wzajemne relacje ze społeczeństwem, którego większość, z różnych powodów, wie niewiele o archeologii, w rozumieniu jej jako dziedziny nauki" (Schadla-Hall, 1999, s. 147; cyt. za: Deskur, 2009, s. 285). Archeologia publiczna zajmuje się aktualnymi relacjami archeologów ze światem zewnętrznym, odnosząc się do problemów, które nie mają związku ze stricte naukową działalnością, lecz stanowią skutek transmisji efektów działalności archeologów do społeczeństwa (Deskur, 2009, s. 286). W jej zakres wchodzą również metody prezentowania społeczeństwu osiągnięć archeologii, sposobów interpretowania przeszłości, a także wszelkie inne aktywności ukierunkowane w stronę publicznego zrozumienia działalności archeologów oraz zaangażowania szerszego ogółu społeczeństwa w ich działania.

O ile na świecie zakres archeologii publicznej odnosi się do szerokiego spektrum działań, w Polsce inicjatywy z zakresu archeologii publicznej nie są tak rozwinięte 
jak w krajach Europy Zachodniej czy w Stanach Zjednoczonych. Aktywności na tym polu koncentrują się prawie wyłącznie na paradygmacie edukacyjnym, w efekcie czego dochodzi do utożsamiania jej z działalnością edukacyjną i różnymi inicjatywami w zakresie upowszechniania wiedzy o przeszłości i dziedzictwie archeologicznym (Kajda, Kobiałka, 2018, s. 79). Przybiera to zróżnicowane formy, które zostały przeze mnie obszernie omówione już w innym miejscu (Pawleta, 2016; zob. też Chowaniec, 2010; Chowaniec, Więckowski, 2012). Są to mianowicie: (1) festyny i festiwale archeologiczne oraz plenerowe imprezy o charakterze archeologicznym (ryc. 1); (2) teatralizacja i „ożywianie” przeszłości, dokonywane w ramach ruchu odtwórstwa historycznego; (3) pełnowymiarowe rekonstrukcje archeologiczne - rezerwaty, skanseny i parki archeologiczne; (4) działalność wystawiennicza i edukacyjna muzeów archeologicznych; (5) filmy i audycje, publikacje popularno-naukowe; (6) upowszechnianie przy wykorzystaniu nowych mediów i technologii, a także za pośrednictwem mediów społecznościowych.

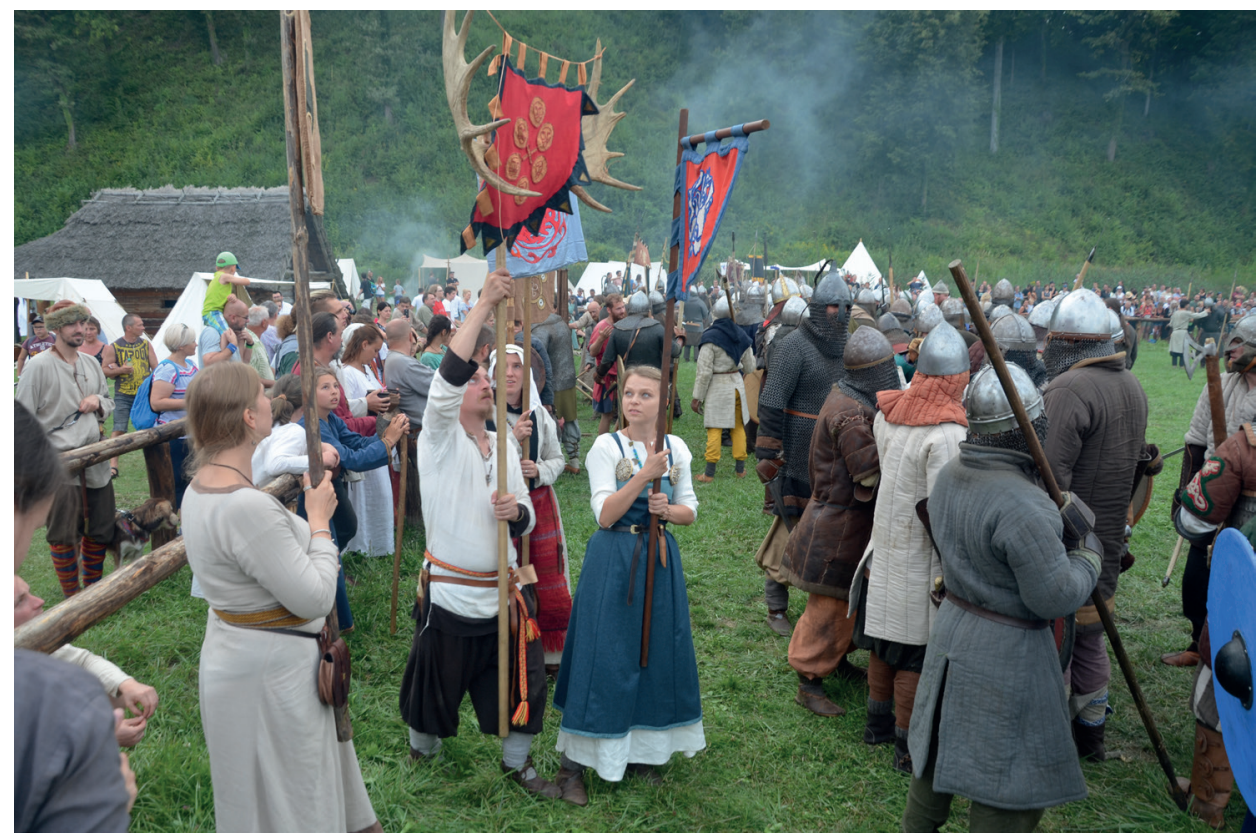

Ryc. 1. Festyn archeologiczny w Karpackiej Troi w 2019 roku (autor: Silar; źródło: Wikimedia Commons, https://commons.wikimedia.org/wiki/File:02019_0045_(1)_Schlachten_der_Rus-War\%C3\%A4ger_und_Saqaliba,_Gefecht_bei_Trcziencza.jpg [dostęp 20.06.2020])

Działania w zakresie upowszechniania w społeczeństwie wiedzy o dziedzictwie archeologicznym bez wątpienia realizują cele archeologii publicznej, wpisując się w postulat archeologii prospołecznej. Ich ideą jest docieranie do ludzi z wiedzą na temat badanej przez nią przeszłości, czym wypełnia etyczne zobowiązania dyscypliny i koncepcję dziedzictwa archeologicznego jako wspólnej własności. Popularyzacja 
w społeczeństwie wiedzy w tym zakresie ma więc swój imperatyw w idei publicznej własności dziedzictwa archeologicznego (zob. Kobyliński, 2001, s. 230-231; 2009, s. 291-292). Opiera się ona na założeniu, że dziedzictwo stanowi wspólną własność całego społeczeństwa, nie zaś wyłączną domenę archeologów, a także odgrywa istotne role społeczne. W związku z tym wszyscy członkowie społeczeństwa winni mieć zapewniony dostęp do tego dziedzictwa, mogą je wykorzystywać dla różnych celów, aczkolwiek w nieniszczący sposób, oraz mają prawo być informowani na jego temat w przystępnej, zrozumiałej i jednocześnie rzeczowej, opartej na naukowych i merytorycznych podstawach, formie. Podobnie i wiedza, którą archeolodzy uzyskują w wyniku badania dziedzictwa archeologicznego, powinna być udostępniania jak najszerszemu gronu zainteresowanych osób. $\mathrm{Na}$ archeologach spoczywa natomiast szczególna odpowiedzialność za oferowaną przez nich społeczeństwu wizję minionych czasów (Kobyliński, 2012, s. 184). Aczkolwiek pod adresem inicjatyw popularyzatorskich często ze strony samych archeologów kierowane są głosy krytyczne - za nierzetelność przedstawień, niedostatek treści merytorycznych, uproszczenia, nadmierną komercjalizację czy zbytnie schlebianie gustom odbiorców - stanowią one jeden z ważniejszych elementów efektywnej ochrony i zarządzania dziedzictwem archeologicznym poprzez edukację.

\section{ARCHEOLOGIA WSPÓLNOTOWA / ZAANGAŻOWANA}

Zbliżonym, aczkolwiek charakteryzującym się pewnymi osobliwościami nurtem na polu relacji między archeologią a społeczeństwem jest tzw. archeologia wspólnotowa (ang. community archaeology). Należy ją zdefiniować jako element szeroko pojętej archeologii publicznej, której kluczowym aspektem jest zaangażowanie osób spoza archeologii w samą dyscyplinę, jak również w szeroko rozumiane działania podejmowane wokół dziedzictwa archeologicznego (Marshall, 2002, s. 2018; Tully, 2007, s. 157-159; Thomas, 2017, s. 14-18). Gemma Tully (2007, s. 176-178; zob. też Zalewska, 2014, s. 30) jako podstawę praktyki archeologii wspólnotowej, obejmującej rozległy zakres komunikacji oraz współpracy między archeologami a społeczeństwem w zakresie tworzenia i prezentacji przeszłości, uznaje konieczność uwzględnienia kilku nieredukowalnych składników. Są to mianowicie: (1) komunikacja i współpraca między archeologami a społecznością lokalną na wszystkich etapach badań; (2) szkolenia, warsztaty oraz ochotniczy udział lokalnych mieszkańców w projektach archeologicznych; (3) publiczna prezentacja badań, postrzegana jako istotny element w przekazywaniu informacji szerszej społeczności; (4) prowadzenie z lokalną ludnością wywiadów umożliwiających ocenę tego, jak reagują oni na badania wykopaliskowe oraz w jaki sposób łączy się to z ich poglądami na przeszłość; (5) tworzenie zasobów edukacyjnych pozwalających zapoznawać osoby w każdym wieku z zagadnieniami odnoszącymi się do dziedzictwa kulturowego; (6) archiwizacja powstałej w wyniku projektów archeologicznych dokumentacji (fotograficznej, filmowej), dokumentującej pracę archeologów i związane z projektem codzienne do- 
świadczenia członków wspólnoty, w celu wizualnego uwydatniania znaczenia wiedzy lokalnych społeczności w interpretacji stanowisk archeologicznych; (7) kontrolowane przez lokalne wspólnoty czerpanie korzyści z rynku turystycznego oraz tworzenie wysokiej jakości alternatyw dla typowych, stereotypowych pamiątek turystycznych.

Głównym celem archeologii wspólnotowej jest więc angażowanie społeczeństwa w archeologiczne projekty badawcze na wszystkich etapach ich realizacji, jak również wzajemna komunikacja i współpraca między archeologami, zarządzającymi dziedzictwem, różnymi ekspertami a społecznościami lokalnymi (Tully, 2007; Thomas, 2017). Działania na polu archeologii wspólnotowej umożliwiają odpowiedzialne włączanie oraz angażowanie się jednostek i społeczności w proces archeologiczny, w tym troskę o wytwarzanie wartości wciąż zmieniającego się dziedzictwa. Wartości te mogą dotyczyć obszarów tożsamościowych, społecznych, edukacyjnych bądź ekonomicznych (Zalewska, 2018, s. 21). W wyniku podejmowanych działań możliwe jest zbliżanie różnych interesariuszy dziedzictwa archeologicznego (osób spoza kręgu specjalistów) dzięki dzielonemu przez nich poczuciu więzi z dawnymi wydarzeniami czy chęci zadbania o materialne dziedzictwo przeszłości (Zalewska, 2018, s. 22). Jak zaznacza dalej cytowana A. Zalewska, sprawia to, że archeologicznemu procesowi badawczemu towarzyszy nie tylko bierne zainteresowanie przedstawicieli różnych grup społecznych, lecz wpisane jest w niego dążenie do ich aktywnego angażowania w badania archeologiczne. W niektórych ważkich społecznie sytuacjach archeologii wspólnotowej przypisuje się „oczyszczającą” czy nawet „terapeutyczną” rolę, zwłaszcza w przypadku trudnej przeszłości, gdzie debaty oscylują wokół takich zagadnień, jak integracja, spójność społeczna, przebaczenie czy pojednanie.

W myśl powyższych założeń działania w zakresie archeologii wspólnotowej są wdrażane przez archeologów wśród społeczności lokalnych lub rdzennych populacji w ramach podejmowanych przez nich projektów badawczych. Polega to na aktywnym włączaniu i angażowaniu lokalnych mieszkańców w proces odkrywania własnej przeszłości, co ma przełożenie na wzrost świadomości społeczności na temat znaczenia przeszłości, jak również zrozumienie teraźniejszych procesów i problemów społecznych (Thomas, 2017, s. 25-26). Działania na polu archeologii wspólnotowej mają więc na celu integrację społeczną, jak również tworzenie i utrzymanie wartości związanych z dziedzictwem oraz z przeszłością (Zalewska, 2014, s. 28).

Inicjatywy z zakresu archeologii wspólnotowej podejmowane są na gruncie polskim od niedawna i sporadycznie, niemniej dotykają one szeregu kwestii będących w centrum zainteresowania współczesnych studiów nad dziedzictwem. Ich podejmowanie wynika z przeświadczenia, że archeolodzy muszą działać we wspólnej sprawie z ludźmi i społecznościami starającymi się zachować i zdobyć szacunek dla ich dziedzictwa kulturowego i archeologicznego (Marciniak, 2015, s. 36).

W praktyce w wielu przypadkach angażowanie społeczności w działania archeologów polega na umożliwieniu miejscowej ludności udziału w pracach archeologicznych, co uważa się za skuteczną metodę wzmacniania pozytywnych skojarzeń z przeszłością, dziedzictwem, jak i z samą dyscypliną. Instruktażowym przykładem może być projekt „Archeologia zaangażowana: społeczeństwo-przeszłość-teledetekcja”, 
zrealizowany w roku 2013 w ramach wspólnej inicjatywy Stowarzyszenia na rzecz Rozwoju Wsi „Razem” z Bieniowa (woj. lubuskie) oraz badaczy z Instytutu Archeologii Uniwersytetu im. Adama Mickiewicza w Poznaniu (Kajda, Kostyrko, 2016; Kajda, Kobiałka, 2018, s. 81-85). Na terenie wczesnośredniowiecznego grodziska, znajdującego się między wsiami Biedrzychowice Dolne oraz Bieniów, przeprowadzono nieinwazyjne badania archeologiczne. Miejsce zostało zaproponowane do badań przez członków stowarzyszenia „Razem”. Badania miały na celu rozpoznanie struktury grodziska wczesnośredniowiecznego przy pomocy metod teledetekcyjnych oraz prezentację efektywności nowoczesnych technik w pracy archeologa, wykorzystywanych do zdobywania informacji na temat przeszłości. Oprócz celów naukowych, ideą projektu było też promowanie lokalnego dziedzictwa archeologicznego i współpraca z lokalną społecznością. W tym celu przeprowadzono wywiady antropologiczne, które opierały się na bezpośrednim dialogu z mieszkańcami miejscowości, w których prowadzone były badania. Miały one za zadanie zbadanie stosunku lokalnej społeczności do przeszłości, otaczającego ich krajobrazu, przybliżenie perspektywy postrzegania przez lokalną społeczność dziedzictwa i związku z nim. Ich celem było także poznanie zapatrywań mieszkańców na archeologię oraz metody pracy archeologów, a także potrzeb i pytań, jakie stawia przed archeologami samo społeczeństwo. Dodatkowo na terenie stanowiska przeprowadzono lekcje dla dzieci z pobliskich szkół. Miały one przybliżyć dzieciom, czym jest archeologia, jak chronić zabytki archeologiczne oraz jakie znaczenie może mieć dla nich dziedzictwo kulturowe.

Innym przykładem w zakresie działań zaangażowanych i inkluzywnych stanowił projekt „Dziedzictwo (dla) wszystkich! Postrzeganie przeszłości i dziedzictwa archeologicznego przez osoby z niepełnosprawnością intelektualną", zrealizowany w 2014 roku przez tę samą grupę badawczy, we współpracy z psychologami z Zespołu Szkół Specjalnych w Żarach. W jego trakcie przeprowadzono serię eksperymentów psychologicznych, w których wzięło udział 14 uczniów (Kajda, Michalik, Kobiałka, 2015a, 2015b; Kajda, Kobiałka, 2018, s. 85-89). Głównym celem projektu było przyczynienie się do polepszenia współpracy między archeologami, muzealnikami czy historykami a osobami z niepełnosprawnością intelektualną. Archeologom zależało na poznaniu, jak te osoby postrzegają przeszłość, w jaki sposób mówią o czasie oraz czy i w jaki sposób dziedzictwo archeologiczne funkcjonuje w ich codziennym życiu. Uczniowie zostali poproszeni m.in. o narysowanie, co kojarzy im się z przeszłością. Wyniki dowiodły, że osoby z niepełnosprawnością intelektualną nie myślą o przeszłości w sposób podobny do osób bez niepełnosprawności. Inne zadania wykazały, że większość pytanych kojarzyła wydarzenia z przeszłości jedynie z sytuacjami z ich życia jako coś, co odnosiło się do wydarzeń bezpośrednio z nimi związanymi. Co więcej, badania potwierdziły, że większość z przebadanych osób posługuje się krótką skalą czasu - nie odnosiły one przeszłości do wydarzeń historycznych, lecz rozpatrywały ją w skali swojego życia. W ramach eksperymentu postanowiono także sprawdzić, jaki wpływ na postrzeganie przeszłości mają wizyty w muzeach i miejscach przekazujących wiedzę o minionych czasach. W tym celu zorganizowano wycieczkę na grodzisko wczesnośredniowieczne w Bieniowie oraz do izby pamięci, w której 
znajdowały się różne eksponaty. Uzyskane w trakcie projektu informacje dowiodły, że osoby z niepełnosprawnością intelektualną rozumieją przeszłość na swój własny sposób. Obserwacja ta stanowi ważne wskazanie dla archeologów, którzy w ramach postulowanego powszechnego dostępu do dziedzictwa powinni starać się przygotowywać programy edukacyjne, które nie będą jedynie spełniały ich oczekiwań, lecz dawały satysfakcję z obcowania z dziedzictwem archeologicznym ludziom o różnej percepcji i pojmowaniu przeszłości.

Inicjatywy, którym przyświecają wytyczne archeologii wspólnotowej, odnoszą się w Polsce głównie do czasów nieodległej przeszłości i lokują w zyskującym coraz większą popularność nurcie, określanym mianem archeologii współczesności. Dotyczą one zwykle badań reliktów wydarzeń XX-wiecznych, zwłaszcza tych naznaczonych bolesnymi wydarzeniami, w przypadku których „,archeologia okazuje się pomocna w kształtowaniu stosunku jednostek i wspólnot pamięci do trudnego i bolesnego dziedzictwa" (Zalewska, 2016, s. 25). W ramach podejmowanych inicjatyw dochodzi do angażowania się w prace archeologiczne lokalnej ludności czy wspólnot pamięci, które czują się związane z miejscami, gdzie są podejmowane prace archeologiczne (Zalewska, 2016, s. 32). Dobrym przykładem są inicjatywy i projekty Anny Zalewskiej: „Archeologia jako antidotum na zapomnienie i wandalizm. Ku przydrożnym lekcjom historii na temat pierwszej wojny światowej (1914-2014)” oraz „Archeologia pojednania. Przydrożne lekcje historii na temat wielkiej wojny nad Rawką jako lekcja pojednania (1915-2015)”. Ich myślą przewodnią było przywracanie „pamięci o miejscach, rzeczach i ludzkich czynach, które zostały niemal całkowicie wymazane z historiografii" (Zalewska, 2017, s. 67), w tym przypadku pamięć i wiedza o użyciu przez siły niemieckie broni chemicznej na froncie wschodnim w trakcie I wojny światowej w 1915 roku$^{8}$. Projekty te miały za zadanie nie tylko upowszechnianie wiedzy o działaniach prowadzonych w tym regionie w czasie trwania I wojny światowej, ale również uwrażliwienie społeczeństwa na dbanie o pamięć o przeszłości jako takiej (Zalewska, 2014, 2019). W trakcie omawianych projektów, prowadzonych w paradygmacie archeologii wspólnotowej, zostały opracowane liczne pomoce dydaktyczne, użyteczne w przywracaniu pamięci o wydarzeniach sprzed lat, wprost odnoszace się do materialnych nośników wiedzy, znaczeń oraz pamięci o Wielkiej Wojnie. Przygotowano i przekazano lokalnej społeczności przystępną publikację traktującą o tych wydarzeniach. Wykonano również siedem tablic informacyjnych, umieszczonych w znaczących miejscach w regionie (Zalewska, 2014, s. 34). Dużo uwagi skierowano również na rozpoznanie nastawienia do materialnych pozostałości po konflikcie sprzed stu lat wśród lokalnej ludności i stanu wiedzy na ich temat oraz „wdrożenie dostosowanych do tego praktyk uspołeczniania pobudzających motywację i wolę troski o te pozostałości” (Zalewska, 2014, s. 34). Przeprowadzono szereg wspólnotowych działań mających na celu wyodrębnienie i zabezpieczenie najbardziej

${ }^{8}$ Zob. https://archeopressja.wordpress.com/2014/06/24/archeologia-pierwszej-wojny-swiatowej-nie-pamiec-ludzka-a-pamiec-materii/ [dostęp: 20.06.2020]; http://www.archeomemory.pl/prospolecznosc/ [dostęp: 20.06.2020]. 
narażonych na zniszczenie obiektów, zorganizowano też skierowane do lokalnej młodzieży warsztaty pt. „Troska o cmentarz w Bolimowskiej Wsi”, na którym pochowani są polegli żołnierze niemieccy.

W zakres działań w tym nurcie wchodzą także badania archeologiczne, prowadzone w ramach tzw. archeologii totalitaryzmu (Ławrynowicz, Żelazko, 2015; Ławrynowicz, 2019), których celem jest poszukiwanie miejsc pochówków i identyfikacja ofiar komunistycznego reżimu w Polsce. Najbardziej znane są prace prowadzone z ramienia IPN na kwaterze „Ł” na Cmentarzu Wojskowym na warszawskich Powązkach, na której w latach 1948-1955 pogrzebano co najmniej 276 więźniów, głównie wybitnych postaci antykomunistycznego ruchu oporu (Szwagrzyk, 2016). Rozpoczęte kilka lat temu poszukiwania miejsc pochówku ofiar komunizmu w różnych miejscach $\mathrm{w}$ kraju spotkało się z niezwykle szerokim i pozytywnym odbiorem społecznym, $\mathrm{w}$ ich prowadzenie włącza się liczne grono wolontariuszy. Dowodzą one, że archeologia, jeśli ukierunkowana jest prospołecznie, może okazywać się pomocna nie tylko w leczeniu traum i w procesach pojednania, ale również przywracaniu sprawiedliwości dziejowej (Zalewska, 2017, s. 67).

$\mathrm{Z}$ racji, że badania zaangażowane nie należą do głównego nurtu w polskiej archeologii, niezwykle ważna w tym względzie jest współpraca między wszystkimi, którym bliska jest taka postawa oraz nagłaśnianie tego typu inicjatyw. Spowoduje to, że integralnie wpiszą się one w szersze działania całego środowiska archeologicznego, stanowiąc niezbywalny element procesu archeologicznego, nie przyjmą zaś formy krótkotrwałej mody. Inicjatywy na tym polu mają potencjał ku uczynieniu z archeologii dyscypliny o dużym znaczeniu z powodu tego, że adresuje ona ważne i aktualne społecznie kwestie. Podkreślę raz jeszcze, kluczowa w tym względzie jest nie tyle relacja archeologów z obiektywną wiedzą naukową na temat przeszłości, lecz ze społeczeństwem, do którego należą. Archeolodzy powinni angażować w swoje badania różne osoby spoza środowiska po to, żeby zdobyć wiedzę o ich problemach czekających na rozwiązanie, przekazać im wyniki własnych prac czy nawet działać razem z nimi. W takiej zaś perspektywie równie ważne jak rozwijanie teorii dyscypliny czy poszerzanie przedmiotowej wiedzy o przeszłości są kondycja i problemy otaczającego świata, którymi z powodzeniem w swej praktyce mogą zajmować się archeolodzy.

\section{QUO VADIS ARCHEOLOGIA? - KONKLUZJE}

Poszukując odpowiedzi na pytanie, dokąd zmierza archeologia, w jednym ze swoich artykułów Stanisław Tabaczyński (1998, s. 19) stwierdził, że jej zadaniem „jedynym, a może najważniejszym - jest nadawanie znaczenia informacyjnego otaczającym nas materialnym świadectwom przeszłości społecznej”. To zadanie stanowiło leitmotiv archeologii, gdy w XIX w. z etapu starożytnictwa formowała się ona w pełnoprawną naukę. Zachowuje ono swoją aktualność - może i bardziej niż kiedyś - również i dzisiaj. Wymaga więc ono od archeologów wprowadzania prospołecznych rozwiązań, większego zaangażowania oraz wzmożonych starań, aby 
komunikować się ze społecznością pozaakademicką. Niepożądana jest jednak sytuacja, gdy archeologia akademicka jako społeczną funkcję będzie miała wbudowaną li tylko obronę swojej własnej pozycji i granic. Niezbędne jest raczej „stworzenie form upowszechniania jej osiągnięć, aby cel, któremu służy, nie stał się celem samym dla siebie" (Konopka, 1983, s. 31). Jest to o tyle istotne, że działania wielu reprezentantów środowiska archeologicznego są nadal zachowawcze i postrzegają oni inicjatywy na polu relacji między archeologią a społeczeństwem jako nienaukowe, dla których nie ma miejsca w głównym nurcie akademickim. W konsekwencji takiego podejścia nie znajdują one uznania w opinii gremiów eksperckich, decydujących choćby o przyznawaniu grantów na badania. Tym ważniejsze wydaje się więc stworzenie dla tego typu działań silnej tożsamości, dzięki której archeologia prospołeczna będzie się mogła rozwijać, mimo braku instytucjonalnego czy grantowego wsparcia.

Aczkolwiek w Polsce brakuje rozwiniętej archeologii publicznej czy wspólnotowej w stopniu takim, jak ma to miejsce w krajach zachodnich, archeolodzy podejmują coraz więcej inicjatyw mających na celu informowanie społeczeństwa na temat m.in. znaczenia archeologii, jej roli w kreowaniu tożsamości społecznych, potrzeby ochrony dziedzictwa archeologicznego czy wzbudzania świadomości na temat konieczności partycypacji społeczności lokalnych w wykonywaniu tego zadania. Nawiązują również współpracę z reprezentantami środowiska pozaakademickiego w celu realizacji działań podejmowanych wokół dziedzictwa archeologicznego na zasadzie partycypacyjnej. Jest to zarówno obiecujące, jak i istotne, aby pokazać, że archeologia może stać się integralną częścią życia publicznego, że jest nie tylko dziedziną nauki, ale przede wszystkim praktycznym działaniem, wynikającym z poczucia zobowiązania wobec całego społeczeństwa.

Współcześnie archeolodzy są zazwyczaj zgodni co do istotności roli, jaką archeologia odgrywa czy może odgrywać w społeczeństwie, aczkolwiek różnie zapatrują się na funkcje, jakie ta dyscyplina ma lub powinna pełnić (np. Hensel, 1973a; Lech, 1995; Tabaczyński, 2001; Rockman, Flatman, 2012; Tabaczyński, Marciniak, Cyngot, Zalewska, 2012). W artykule akcentowałem głównie dwie z nich: funkcję edukacyjną (popularyzatorską), polegającą na przekazywaniu społeczeństwu wiedzy na temat przeszłości, oraz dyskursywną, związaną z udziałem archeologii w kluczowych debatach teraźniejszości i angażowaniem osób spoza archeologii w działania wokół archeologii i dziedzictwa archeologicznego, w czym zawiera się zagadnienie społecznej „użyteczności” tej dyscypliny i tworzonej przez nią wiedzy (Lech, 1995, s. 93-96; Marciniak, 2011, s. 179). Nie ma to na celu dyskredytowanie dwóch pozostałych, równie ważnych funkcji, mianowicie naukowej (poznawczej), polegającej ma powiększaniu zasobu wiedzy na temat przeszłości, oraz konserwatorskiej, związanej z ochroną dziedzictwa archeologicznego. Są one tak samo ważne i stanowią o całości procesu archeologicznego.

$\mathrm{Z}$ racji, że jednym z głównych zadań archeologii jest tworzenie wiedzy na temat najdawniejszych dziejów społeczności ludzkich, ex definitione jest więc ona zorientowana społecznie. Wyznacznikami jej funkcji społecznych są zaś postrzeganie wy- 
ników badań archeologicznych oraz sposoby rozumienia znalezisk archeologicznych przez społeczeństwo (Lech, 1995, s. 93). Społeczne znaczenie archeologii bierze się tym samym z realizowanego przez nią naukowego poznawania rzeczywistości pradziejowej, dostarczania wiedzy w tym zakresie, udostępniania społeczeństwu (np. za pośrednictwem wystaw muzealnych) zbiorów zabytków archeologicznych czy popularyzowania wyników swych odkryć. Łączy się ono także z praktyczną rolą tej dyscypliny, wynikającą z treści przedmiotowej archeologii w aspekcie m.in. użytków czynionych z zabytków archeologicznych i wiedzy na ich temat, a także działalnością instytucji o charakterze archeologicznym.

Zagadnienie społecznej użyteczności archeologii zawiera się w odpowiadaniu na społeczno-kulturowe zapotrzebowania na kreowanie przez archeologię wizerunku przeszłości, społeczne oczekiwania względem tej dyscypliny, a także zdolność archeologii do odpowiedzi na wyzwania współczesnego świata i uczestniczenie w dialogu społecznym. Mieści się w niej także angażowanie się w rozwiązywanie współczesnych problemów społecznych, w czym przejawia się etyczna odpowiedzialność archeologów (np. Sabloff, 2008). W takim zaś zakresie archeologia służy „nie tylko poznaniu przeszłości, lecz także lepszemu zrozumieniu teraźniejszości oraz sensowniejszemu planowaniu przyszłości” (Hensel, 1973b, s. 276). Archeologia jako nauka będąca częścią kultury ma więc pełnić szeroko pojęte funkcje społeczne, a także odgrywać istotną rolę w procesie kulturotwórczego oddziaływania na świadomość społeczną, przez propagowanie i rozwijanie poczucia więzi historycznej lokalnych społeczności z własnym środowiskiem, jego historią i pradziejami. Ponadto do jej zadań należy współtworzenie teraźniejszości i kultury, której jest częścią i w której funkcjonuje (Mamzer, 2011, s. 35). Angażowanie się w takie działania może doprowadzić do wzmocnienia pozycji tej dyscypliny w świetle licznych negatywnych zjawisk i procesów, które na nią oddziałują przez wyraźne zaakcentowanie jej znaczenia w rozległym i wielowątkowym dyskursie na temat przeszłości i dziedzictwa archeologicznego, zwłaszcza zaś w kontekście procesów ich współczesnego interpretowania, prezentowania, udostępniania oraz ochrony. To, w jakim jednak zakresie działania na tym polu będą skutecznie podejmowane i realizowane, zwłaszcza w świetle trudnych do przewidzenia jeszcze konsekwencji w epoce postpandemicznej, związanej z wirusem COVID-19, pokaże najbliższa przyszłość.

\section{BIBLIOGRAFIA}

Ashworth, G. J.

2007 Sfragmentaryzowane dziedzictwo: sfragmentaryzowany instrument sfragmentyzowanej polityki. W: M. A. Murzyn, J. Purchla (red.), Dziedzictwo kulturowe w XXI wieku. Szanse i wyzwania (s. 29-42). Kraków: Międzynarodowe Centrum Kultury.

Chowaniec, R.

2010 Dziedzictwo archeologiczne w Polsce: formy edukacji i popularyzacji. Warszawa: Instytut Archeologii UW. 
Chowaniec, R. Więckowski, W. (red.)

2012 Archaeological heritage: methods of education and popularization. Oxford: Archaeopress.

Deskur, K.

2009 Idea public archaeology - edukacja archeologiczna i popularyzacja archeologii. Fontes Archaeologici Posnanienses, 45, 283-292.

Gürsu, I. (red.)

2019 Public archaeology: theoretical approaches and current practices. London: Oxbow Books.

Hensel, W.

$1973 \mathrm{a}$

Zakres i zadania archeologii. Slavia Antiqua, 20, 131-135.

1973b Archeologia żywa. Warszawa: Wydawnictwa Artystyczne i Filmowe.

Holtorf, C.

2005 From Stonehenge to Las Vegas. Archaeology as popular culture. Walnut Creek, CA: AltaMira Press.

Kajda, K., Kobiałka, D.

2017 Archeologie współczesności jako odpowiedź na kryzys dyscypliny. Ochrona Zabytków, 2(271), 27-45.

2018 The past and present of public archaeology in Poland: between educating and engaging local communities. CPAG, 28, 77-91.

Kajda, K., Kostyrko, M.

2016 Contemporary dimension of heritage promotion - towards socially engaged archaeology. Sprawozdania Archeologiczne, 68, 9-23.

Kajda, K., Michalik, T., Kobiałka, D.

2015a Heritage for all. A contribution to the inclusion of people with intellectual disabilities in archaeology: a Polish perspective. Current Swedish Archaeology, 23, 131-156.

2015b Angażując osoby pozostawione na marginesie. Archeologia włączająca (inclusive archaeology) i badanie sposobów postrzegania przeszłości przez osoby z niepełnosprawnością intelektualną. Biografia Archeologii, 1(2), 4-12. Online: http://archeo.edu.pl/biografia2017/ wp-content/uploads/2015/05/Biografia_Archeologii_vol1_2.pdf [dostęp: 20.06.2020].

Kobyliński, Z.

2001 Teoretyczne podstawy konserwacji dziedzictwa archeologicznego. Warszawa: Fundacja Res Publica Multiethnica, Instytut Archeologii i Etnologii PAN.

2002 Archaeology on the ruins of ivory towers. What sort of theory do we need? W: P. F. Biehl, A. Gramsch, A. Marciniak (red.), Archaeologies of Europe. History, methods and theories (s. 421-424). Münster: Waxmann.

2009 Wtasność dziedzictwa archeologicznego: idee - problemy - kontrowersje. Warszawa: Instytut Archeologii i Etnologii PAN.

2012 Etyka w archeologii. W: S. Tabaczyński, A. Marciniak, D. Cyngot, A. Zalewska (red.), Przeszłość społeczna. Próba konceptualizacji (s. 178-189). Poznań: Wydawnictwo Poznańskie.

Konopka, M.

1983 Ochrona zabytków archeologicznych w Polsce. Warszawa: Ministerstwo Kultury i Sztuki, Ośrodek Dokumentacji Zabytków.

Kozakiewicz, J.

2012 Marketing jako narzędzie w popularyzacji archeologii. W: J. Gancarski (red.), Skanseny archeologiczne $i$ archeologia eksperymentalna (s. 645-661). Krosno: Muzeum Podkarpackie w Krośnie.

Lech, J.

1995 Social functions of archaeology in XX century. W: M. Kuna, N. Venclová (red.), Whither archaeology? Papers in honour of Evžen Neustupný, (s. 93-96). Praha: Institute of Archaeology, Academy of Sciences of the Czech Republic. 
Ławrynowicz, O.

2019 Archaeology of us and the local identity. An interdisciplinary context. Acta Universitatis Lodziensis. Folia Archaeologica, 34, 45-57.

Ławrynowicz, O., Żelazko, J. (red.)

2015 Archeologia totalitaryzmu. Ślady represji 1939-1956. Łódź: Instytut Pamięci Narodowej.

Mamzer, $\mathrm{H}$.

2011 O archeologicznej autokreacji. W: A. Marciniak, D. Minta-Tworzowska, M. Pawleta (red.), Współczesne oblicza przeszłości (s. 25-38). Poznań: Wydawnictwo Poznańskie.

Marciniak, A.

2011 Contemporary Polish archaeology in global context. W: L. R. Lozny (red.), Comparative archaeologies. A sociological view of the science of the past (s. 179-194). New York: Springer.

2015 The aftermath of Malta. W: M. van der Dries, S. J. van der Linde, A. Strecker (red.), Fernweh. Crossing borders and connecting people in archaeological heritage management. Essays in honour of prof. Willem J.H. Willems (s. 34-37). Leiden: Sidestone Press.

Marshall, Y.

2002 What is community archaeology? World Archaeology, 34(2), 211-219.

Matsuda, A, Okamura, K. (red.)

2011 New perspectives in global public archaeology. London: Springer.

McGimsey, C. R.

1972 Public archaeology. New York: Seminar Press.

Merriman, N. (red.)

2004 Public archaeology. London: Routledge.

Moshenska, G. (red.)

2017 Key concepts in public archaeology. London: UCL Press.

Musiał-Gąsiorowska, A.

2012 Prawne i organizacyjne aspekty popularyzacji dziedzictwa kulturowego - pryncypia. Przegląd Prawa Publicznego, 3/2019, 27-37.

Olivier, L.

2013 The business of archaeology is the present. W: A. González-Ruibal (red.), Reclaiming archaeology. Beyond the tropes of modernity (s. 117-129). London - New York: Routledge.

Pałubicka, A.

1997 Filozofia kultury a archeologia. W: J. Ostoja-Zagórski (red.), Jakiej archeologii potrzebuje współczesna humanistyka (s. 121-135). Poznań: Instytut Historii UAM.

Pawleta, M.

2016 Przeszłość we współczesności. Studium metodologiczne archeologicznie kreowanej przeszłości w przestrzeni społecznej. Poznań: Wydawnictwo Naukowe UAM.

Rockman, M., Flatman, J. (red.)

2012 Archaeology in society. Its relevance in the modern world. New York: Springer.

Sabloff, J. A.

2008 Archaeology matters: action archaeology in the modern world. Walnut Creek, CA: Left Coast Press, INC.

Schadla-Hall, T.

1999 Editorial: public archaeology. European Journal of Archaeology, 2(2), 147-158.

2006 Public archaeology in the twenty-first century. W: R. Layton, S. Shennan, P. Stone (red.), A future for archaeology. The past in the present (s. 75-82). London: UCL Press.

Schlanger, N., Aitchison, K. (red.)

2010 Archaeology and the global economic crisis. Multiple impacts, possible solutions. Tervuren: Culture Lab Editions. 
Shanks, M.

2012 The archaeological imagination. Walnut Creek, CA: Left Coast Press, INC.

Skeates, R., McDavid, C., Carman, J. (red.)

2012 The Oxford handbook of public archaeology. Oxford: Oxford University Press.

Smith, L.

2006 Uses of heritage. London, New York: Routledge.

2016 „Zwierciadło dziedzictwa”: narcystyczna iluzja czy zwielokrotnione odbicie? Rocznik Antropologii Historii, 6(9), 25-44.

Szmygin, B.

2007 Dziedzictwo w transformacji. Polskie doświadczenia. W: M. A. Murzyn, J. Purchla (red.), Dziedzictwo kulturowe w XXI wieku. Szanse i wyzwania (s. 129-138). Kraków: Międzynarodowe Centrum Kultury.

Szmygin, B. (oprac. i wybór)

2015 Vademecum konserwatora zabytków. Międzynarodowe normy ochrony dziedzictwa kultu$r y$. Warszawa: Polski Komitet Narodowy ICOMOS.

Szwagrzyk, K.

2016 Archeologia zbrodni jako źródło katharsis społeczeństw posthumanistycznych. W. A.

Zalewska (red.), Archeologia wspótczesności (s. 197-206). Warszawa: SNAP, Oddział w Warszawie.

Tabaczyński, S.

1987 Archeologia średniowieczna: problemy, metody, źródła, cele badawcze. Wrocław: Zakład Narodowy im. Ossolińskich, Wydawnictwo PAN.

1997 Ochrona dziedzictwa archeologicznego w Polsce i jej konteksty. Przegląd problemów. W: Aktualne zagrożenia dziedzictwa archeologicznego. Materiały z Konferencji Ogólnopolskiej, Poznań 17 kwietnia 1997 r. (s. 26-30). Poznań: Muzeum Archeologiczne.

1998 Międzynarodowy kontekst ochrony dziedzictwa archeologicznego. W: Z. Kobyliński (red.), Ochrona dziedzictwa archeologicznego w Europie (s. 15-19). Warszawa: Generalny Konserwator Zabytków, SNAP.

2001 Archeologia na progu XXI wieku. W: J. Lech (red.), Archeologia na progu III tysiaclecia (s. 39-51). Warszawa: KNPiP WNS PAN.

Tabaczyński, S., Marciniak, A., Cyngot, D., Zalewska, A. (red.)

2012 Przeszłość spoteczna. Próba konceptualizacji. Poznań: Wydawnictwo Poznańskie.

Thomas, $\mathrm{S}$.

2017 Community archaeology. W: G. Moshenska (red.), Key concepts in public archaeology (s. 14-30). London: UCL Press.

Tully, G.

2007 Community archaeology: general methods and standards of practice. Public Archaeology, 6(3), 155-187.

Williams, H., Pudney, C., Ezzeldin, A. (red.)

2019 Public archaeology: arts of engagement. Oxford: Archaeopress.

Wrzesiński, J., Wyrwa, A. M. (red.)

2010 Przeszłość dla przyszłości. Problemy edukacji muzealnej. Materiaty Konferencji z okazji Jubileuszu 40-lecia Muzeum Pierwszych Piastów na Lednicy, Lednica 11-13 września

Zalewska, A. 2009 r. Lednica: Muzeum Pierwszych Piastów na Lednicy.

2014 Prospołeczna, partycypacyjna i „wspólnotowa” archeologia bliskiej przeszłości jako sposób na nadawanie sensu trwaniu (ludzi i rzeczy) oraz jako antidotum na niedostatki wiedzy i trywializację przeszłości. Studia Humanistyczne AGH, 13(2), 19-39.

2016 Archeologie współczesnych konfliktów jako praktykowanie prospołecznej archeologii. Przykład wartości epistemologicznej i aksjologicznej archeologii Wielkiej Wojny. W: A. Zalewska (red.), Archeologia wspótczesności (s. 125-140). Warszawa: SNAP, Oddział w Warszawie. 
2017 Archeologia czasów współczesnych i (nie)moc działania materialnych śladów Wielkiej Wojny w Polsce. Ochrona Zabytków, 2(271), 47-77.

2018 Archeologia prospołeczna i uspołeczniona (public archaeology) z perspektywy polskiej. W: J. Wojdon (red.), Historia w przestrzeni publicznej (s. 17-26). Warszawa: PWN.

Zalewska, A. (red.)

2019 Archeologiczne przywracanie pamięci o Wielkiej Wojnie w rejonie Rawki i Bzury (19141915). Warszawa: Wydawnictwo Instytutu Archeologii i Etnologii Polskiej Akademii Nauk.

\author{
SOCIALLY RESPONSIBLE ARCHAEOLOGY. PUBLIC \\ AND COMMUNITY ARCHAEOLOGY ACIVITIES IN POLAND
}

\title{
Sum mary
}

The following article aims to conceptualize the social role of archaeology and archaeological heritage in the present. Apprehending both archaeology and heritage from the perspective of the contemporaneity it argues that the role of archaeology should not be limited only to knowing the truth about the past, but of key importance is the relationship of archaeologists with society to which they belong to. An aim of underlying this relationship is to define and shape people's connection with archaeological heritage through its dissemination and making it public. The objective is twofold. First, making archaeological heritage accessible as well as involving the public in activities undertaken around heritage resources results in its understanding and protection, being in the interest of society, archaeological heritage and the discipline itself. Second, the openness of archaeology to society helps to strengthen its position and define its important social role as well as to attribute social activities of archaeologists with a deeper meaning.

Having adopted such a perspective, the following article discusses activities located within the domain of public/community archaeology archaeology. Although in Poland - in contrast to other countries - public archaeology does not exist here in all theoretically possible aspects and practical implementations, yet archaeologists have undertaken more and more initiatives to inform the public about the importance of archaeology, its role in creating local identities or about public responsibilities in protection of archaeological heritage. Archaeologists also more frequently than before cooperate with representatives of the non-academic community in order to implement together activities undertaken around archaeological heritage and involve them in some tasks in a participatory manner.

The text outlines the legal and doctrinal context of initiatives aimed at disseminating cultural and archaeological heritage and involving the public in heritage issues. It discusses, inter alia, "National Program for the Protection of Monuments and the Care of Monuments", "The Council of Europe Framework Convention on the Value of Cultural Heritage for Society", signed in Faro in 2005, "European Convention on the Protection of the Archaeological Heritage" ratified by Poland in 1996 and formal codes of practice for Polish archaeologists..

One of the important elements highlighted in contemporary approaches to cultural (archaeological) heritage is the issue of its presentation, dissemination and sharing with a wide audience. In a case of archaeology, it has been limited to dissemination and educating the public about archaeology and the past. These activities define the educational function of archaeology, which consists of providing the public with knowledge about the past that is studied by archaeology. The aim of 
archaeologists efforts is to shape the knowledge about the past by delivering the public information (about e.g. the results of archaeological research, new discoveries or archaeological interpretations) in a manner adjusted to the perception of the average recipients. It also aims to increase public awareness of the need to protect archaeological heritage and the obligations of archaeologists and other members of society in this regard.

Then, the main forms of disseminating and educational activities undertaken by archaeologists in Poland are discussed. They take various forms, namely: (1) archaeological festivals and open-air archaeological events; (2) theatralisation and "reliving" of the past within historical re-enactment initiatives; (3) full-size archaeological reconstructions - reserves, open-air museums and archaeological parks; (4) exhibition and educational activities of archaeological museums; (5) films, broadcasts and popular science publications; (6) dissemination with the use of new media and through social media.

Another issue addressed in the text are community-oriented activities and initiatives that go beyond educating the general public about the past and archaeology and seek to involve local communities in activities around archaeology and archaeological heritage. Community archaeology initiatives in Poland have been undertaken recently and sporadically, but they nevertheless touch upon a number of issues that are at the heart of present-day heritage studies. They are based on the conviction that archaeologists have to cooperate with people and communities which try to protect and gain respect for their own cultural and archaeological heritage.

The article concludes with the statement that the openness of archaeology to society helps to strengthen its current social position, determine its role in the world and attributes activities of archaeologists with deeper meaning. It is both promising and important to show that archaeology has a chance to become an integral part of public life; it is not only a science, but above all a practical activity resulting from its obligations to the whole society. 